\title{
Balances of suspended matter and radionuclides in inflow and outflow waters of Orlík Reservoir, Vltava River (Czech Republic)
}

\author{
E. Hanslík, D. Ivanovová and M. Kluganostová \\ T. G. Masaryk Water Research Institute, Public Research Institution, \\ Prague, Czech Republic
}

\begin{abstract}
This study evaluates distribution and dynamics of suspended matter, strontium 90 and caesium 137 in Orlík reservoir. In the case of suspended matter and caesium 137, 85.8\% and 60.6\% respectively was deposited in the reservoir during the period 2000-2006 while during the period 1997-2006 the outflow of strontium 90 from the reservoir exceeded the inflow by $31 \%$.
\end{abstract}

\section{INTRODUCTION}

Concentrations of suspended matter, strontium 90 and caesium 137 were measured in surface waters near Temelín Nuclear Power Plant as a component of studies that were focused on evaluation of possible impacts of the reservoir on hydrosphere. The observations were carried out on tributaries of the reservoirs, involving the Vltava River at Hněvkovice (water abstraction site for Temelín Nuclear Power Plant) whose long-term annual discharge $Q_{a}$ is $30.6 \mathrm{~m}^{3} / \mathrm{s}$, the Lužnice River at Koloděje with annual discharge $Q_{a}$ of $23.6 \mathrm{~m}^{3} / \mathrm{s}$, the Otava River at Topělec with annual discharge $Q_{a}$ of $23.5 \mathrm{~m}^{3} / \mathrm{s}$, and at the outflow from the reservoir on the Vltava River at Solenice with annual discharge $\mathrm{Q}_{\mathrm{a}}$ of $83.4 \mathrm{~m}^{3} / \mathrm{s}$ (the river site located downstream from the outflow of wastewater from Temelín Nuclear Power Plant). The reservoir storage capacity is $720 \cdot 10^{6} \mathrm{~m}^{3}$. The observation started in 1990 except for the observation of strontium 90 which started in 1997. The study area was affected by radioactive fall-outs resulting from tests of nuclear weapons and from the Chernobyl accident in the last century. The results of the measurements showed that the activities of strontium 90 and caesium 137 in surface water and components of the hydrosphere (bottom sediments, fish and water plant biomass) in the proximity of Temelín Nuclear Power Plant were gradually decreasing. Concentrations of caesium 137 between the tributaries of Orlík reservoir and downstream observation sites exhibited a decrease while moderate increase was identified for the concentrations of strontium 90 [1, 2]. The paper describes results of the analysis of depositions of suspended matter, strontium 90 and caesium 137 in Orlík reservoir.

\section{METHODS}

Large samples of 501 were taken from sampling points shown in Figure 1 with annual frequency of four samples to determine concentrations of the radionuclides. Samples were immediately stabilized with nitric acid to $\mathrm{pH} 1$ and then, after transportation to the laboratory, condensed by vaporization. The vaporized samples were annealed and closed into Petri dishes. The gamma-spectrometry measurement duration was set up in accordance with minimum detected activity (MDA) of caesium 137, which is $0.5 \mathrm{mBq} / \mathrm{l}$. Strontium 90 was detected from the residuum after annealing via detection of yttrium 90 after radiochemical separation. Value of MDA of strontium 90 was $3 \mathrm{mBq} / \mathrm{l}$. 


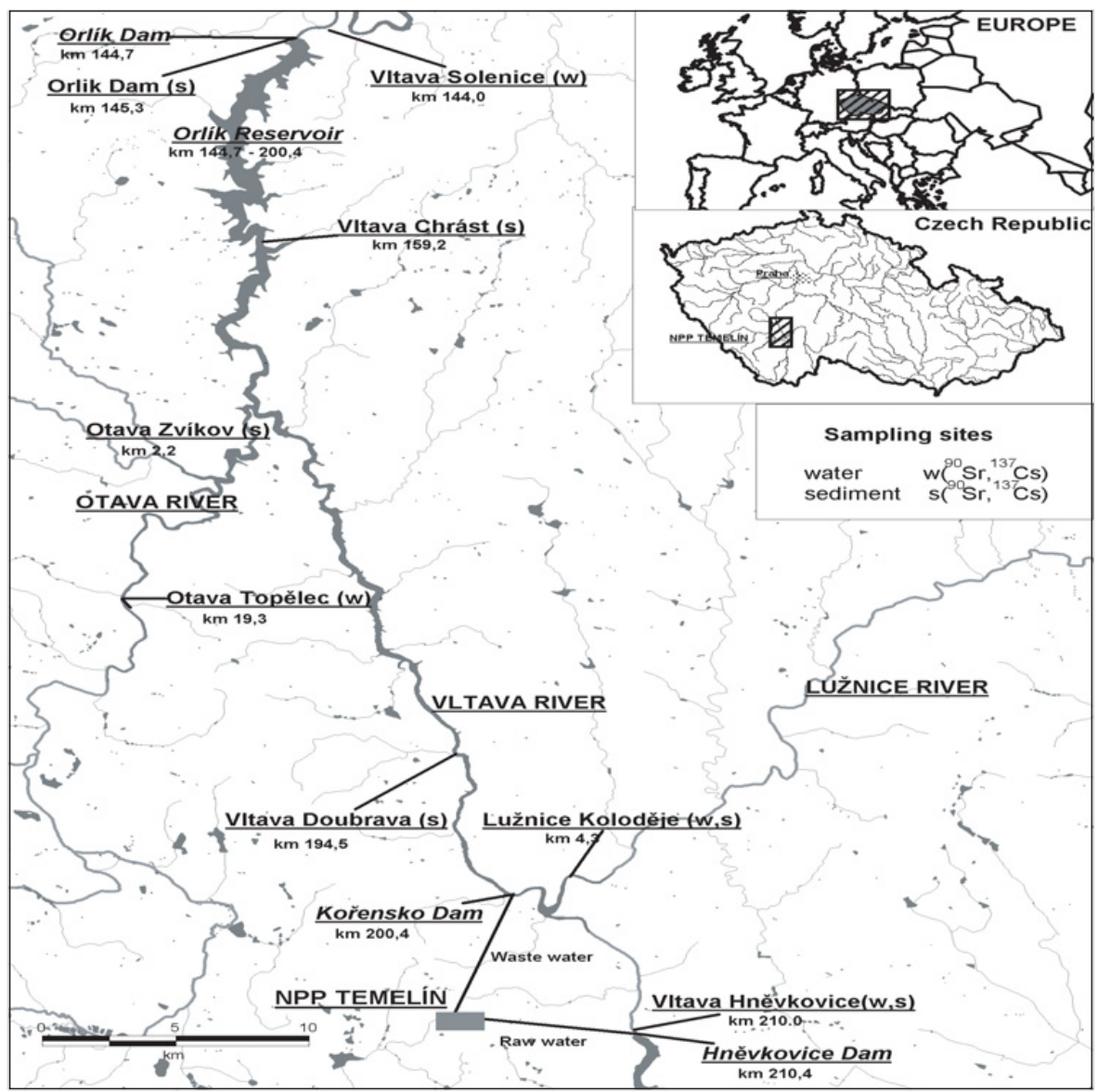

Figure 1. Location of points for water and sediment sampling from Orlík reservoir, its tributaries, and the outflow.

Concentrations of suspended matter (SM) were measured in parallel samples via gravimetry with the limit of detection (LD) $2 \mathrm{mg} / \mathrm{l}$. Values of annual mean river discharges were provided by the Czech Hydrometeorological Institute.

Balance calculations of substances with concentrations below the minimum detected activities and limits of detection were carried out for values of 0.5 of these limits.

\section{RESULTS AND DISCUSSION}

Annual mean concentrations of suspended matter in samples from Orlík reservoir and its tributaries were used together with annual mean flows for the balance assessment.

The annual depositions of suspended matter in the reservoir were calculated as follows:

$$
D_{S M, m, j}=\left(\sum_{t^{\prime} 1}^{n} c_{S M, j, t} \cdot Q_{j, t} \cdot t+c_{S M, j, i a} Q_{j, i a} \cdot t-c_{S M, j, o} \cdot Q_{j, o} \cdot t\right) \cdot 10^{-3}
$$




\begin{tabular}{|c|c|c|}
\hline where & $\mathrm{D}_{S M, m, j}$ & $\begin{array}{l}\text { Deposition of suspended matter in Orlík reservoir in } \\
\text { individual years }(j) \text { in t/year }\end{array}$ \\
\hline & $\mathrm{c}_{S M, j, t}$ & $\begin{array}{l}\text { Annual mean concentration of suspended matter }(j) \text { in tributaries } \\
(t) \text { - Vltava at Hněvkovice, Lužnice at Koloděje and Otava at } \\
\text { Topělec in } \mathrm{kg} / \mathrm{m}^{3}\end{array}$ \\
\hline & $\mathrm{c}_{S M, j, i a}$ & $\begin{array}{l}\text { Annual mean concentration of suspended matter }(j) \text { in the inflow } \\
\text { from inter-basin area }(i a) \text { - derived from Vltava at Hněvkovice, } \\
\text { Lužnice at Koloděje and Otava at Topělec river sites in } \mathrm{kg} / \mathrm{m}^{3}\end{array}$ \\
\hline & $\mathrm{C}_{S M, j, o}$ & $\begin{array}{l}\text { Annual mean concentration of suspended matter }(j) \text { in the outflow } \\
\text { from Orlík reservoir - Vltava at Solenice in } \mathrm{kg} / \mathrm{m}^{3}\end{array}$ \\
\hline & $\mathrm{Q}_{j, t}$ & $\begin{array}{l}\text { Annual mean inflow }(j) \text { from tributaries }(t) \text { - Vltava at } \\
\text { Hněvkovice, Lužnice at Koloděje and Otava at Topělec in } \mathrm{m}^{3} / \mathrm{s}\end{array}$ \\
\hline & $\mathrm{Q}_{j, i a}$ & Annual mean inflow $(j)$ from the inter-basin area in $\mathrm{m}^{3} / \mathrm{s}$ \\
\hline & $\mathrm{Q}_{j, o}$ & $\begin{array}{l}\text { Annual mean outflow }(j) \text { from Orlík reservoir - Vltava } \\
\text { at Solenice in } \mathrm{m}^{3} / \mathrm{s}\end{array}$ \\
\hline & $\mathrm{t}$ & Year duration in $\mathrm{s}$ \\
\hline
\end{tabular}

The depositions of suspended matter ranged in the individual years from 17910 to 54903 tons per year. The average value was 29910 tons and the maximum value was associated with the maximum annual mean flow in the year 2002.

Relationship between the suspended matter deposition in Orlík reservoir and the outflow from the reservoir in the Vltava River at Solenice sampling site is expressed by linear equation:

$$
D_{S M, m, j}=k \cdot Q_{j, o}+q
$$

where $k, q$ are parameters of the linear equation.

This relationship is shown in Figure 2. Its correlation coefficient is 0.81 (the correlation coefficient of power correlation is 0.70 ).

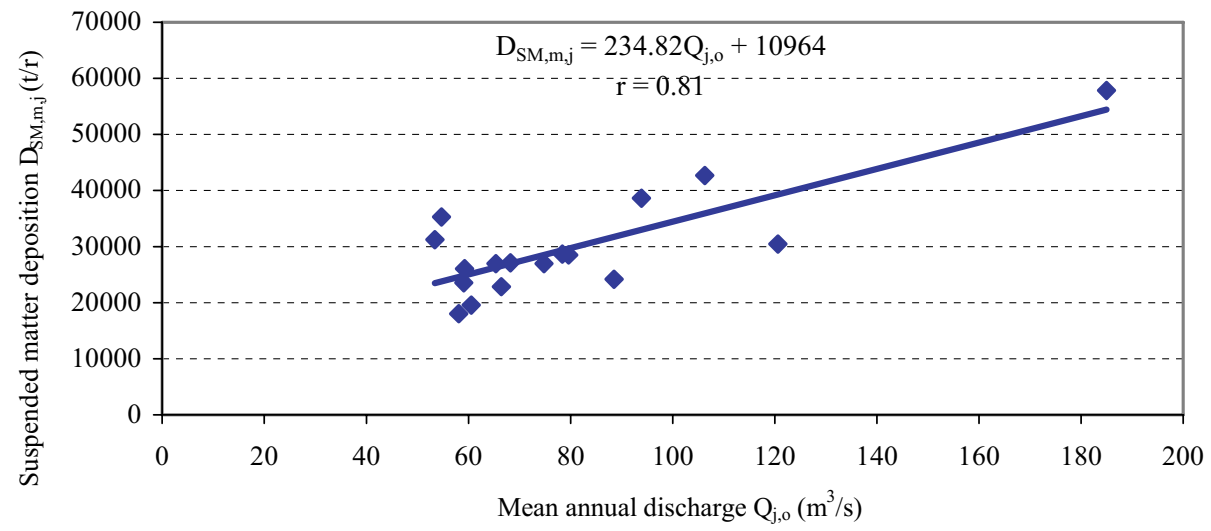

Figure 2. Dependence of the suspended matter deposition in Orlík reservoir on the annual mean flow in the Vltava River at Solenice sampling site.

The derived relationship is in accordance with the assumption that higher water flow causes increased flow of suspended matter and thus its increased sedimentation and deposition. 
The deposition of suspended matter was also calculated for individual years by the following formula and expressed in percentages:

$$
D_{S M, j}=\frac{\sum_{t=1}^{n} c_{S M, j, t} \cdot Q_{j, t}+c_{S M, j, i a} \cdot Q_{j, i a}-c_{S M, j, o} \cdot Q_{j, o}}{\sum_{t=1}^{n} c_{S M, j, t} \cdot Q_{j, t}+c_{S M, j, i a} \cdot Q_{j, i a}} \cdot 100
$$

where $\quad \mathrm{D}_{S M, j} \quad$ is the deposition of suspended matter in Orlík reservoir in individual years $(j)$ in $\%$

The deposition of suspended matter in Orlík reservoir expressed in percentages did not show temporal dependence. It was identified in the range from 71 to $95 \%$ with the average value of $85.5 \%$.

Based on the results of the caesium 137 activity monitoring in all substances in water (dissolved as well as undissolved substances) in the identical sites as used for suspended matter, the deposition of caesium 137 was determined by the formula:

$$
D_{A, 137 C s, j}=\left(\sum_{t=1}^{n} c_{137 C s, j, t} \cdot Q_{j, t} . t+c_{137 C s, j, i a} \cdot Q_{j, i a} \cdot t-c_{137 C s, j, o} \cdot Q_{j, o} . t\right) \cdot 10^{-9}
$$

where $\quad \mathrm{D}_{A, 137 C s, j} \quad$ Deposition of caesium 137 in individual years $(j)$ in GBq/year

$\mathrm{c}_{137 C s, j, t} \quad$ Annual mean activity of caesium $137(j)$ in tributaries $(t)$ of Orlík reservoir - Vltava at Hněvkovice, Lužnice at Koloděje and Otava at Topělec in $\mathrm{Bq} / \mathrm{m}^{3}$

$\mathrm{c}_{137 C s, j, i a} \quad$ Annual mean activity of caesium $137(j)$ the inflow from interbasin area (ia) - derived from Vltava at Hněvkovice, Lužnice at Koloděje and Otava at Topělec river sites in $\mathrm{Bq} / \mathrm{m}^{3}$

$\mathrm{c}_{137 C s, j, o} \quad$ Annual mean activity of caesium $137(j)$ in the outflow from Orlík reservoir - Vltava at Solenice in $\mathrm{Bq} / \mathrm{m}^{3}$

Annually deposited activities of caesium 137 were detected in the range from 1.8 to $19.2 \mathrm{GBq} / \mathrm{year}$.

For caesium 137, the assessment included temporal dependence of its deposition in Orlík reservoir in the period 1990-2006. For description of its trend the kinetic equation of the first order was used:

$$
\ln D_{A, 137 C s, j}=-\lambda_{e f} \cdot t+q
$$

where $\quad \lambda_{\text {ef }} \quad$ Effective (observed) constant of the decrease in caesium 137 deposition

q Deposition of caesium 137 at the beginning of the observation in $\mathrm{GBq} /$ year

The results are shown in Figure 3. The correlation coefficient is 0.68 and observed half life of the decrease in caesium 137 deposition is 8.0 years. The temporal trend of the decrease is in harmony with observed trends in caesium 137 activity in all substances in water and bottom sediments in the study area [2]. The deposition of caesium 137 was greater in 2002 consequently to higher precipitation in this year as compared to that in the other years of the period 1996-2006. The results of the study showed that residual contamination by caesium 137 exceeds significantly its contribution from waste water discharges from Temelín Nuclear Power Plant. Annual discharges of caesium 137 were 0.0004 GBq/year 
in 2002, $0.009 \mathrm{GBq} /$ year in 2003, 0.027 GBq/year in 2004, 0.102 GBq/year in 2005, 0.082 GBq/year in 2006 and $0.052 \mathrm{GBq} /$ year in 2007 [3].

The percentage values of the caesium 137 deposition were in the range from 36 to $76 \%$ with the average of $60.6 \%$. The mean percentage caesium 137 deposition was lower than that of the suspended matter. This result indicates that a part of caesium 137 concentration is dissolved in water. With regard to the uncertainty of the detection of very low caesium 137 activities and low frequency of the monitoring (4 samples per year), the range of the individual values around the mean is relatively small. The year 2002 which was extremely wet (high precipitation) has consequently the lowest value (in percentages but not in absolute values) of the caesium 137 deposition (40\%) similarly to the lowest value of the percentage deposition of suspended matter derived for this year.

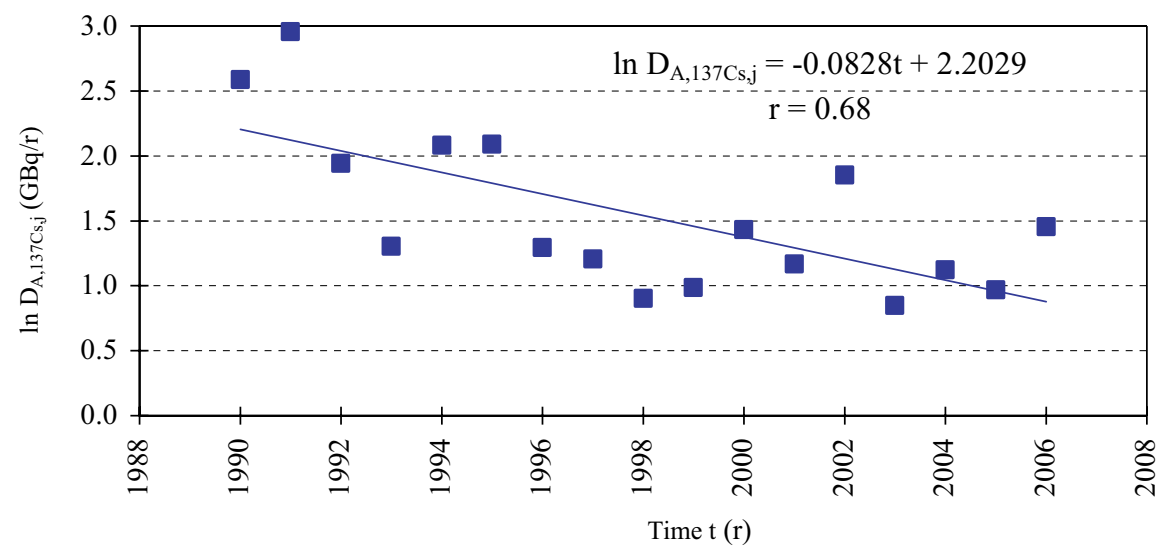

Figure 3. Decrease in caesium 137 deposition in Orlík reservoir during 1990-2006.

As in the case of caesium 137, the balance of strontium $90\left(\mathrm{D}_{\mathrm{A}, 90 S r, j}\right)$ was evaluated in the tributaries and in the outflow from Orlík reservoir. For the calculation by using Equation (4), the annual mean activity of strontium $90\left(\mathrm{c}_{90 S r, j}\right)$ was used instead of the caesium 137 activity $\left(\mathrm{c}_{137 C s, j}\right)$. The results showed that the activity of strontium 90 in the outflow from the reservoir exceeds that in the tributaries and in the water from the inter-basin area. The annually discharged concentration of strontium 90 during the study period was in the range from 1.1 to $8.7 \mathrm{GBq} /$ year. It was also derived for strontium 90 that the residual pollution exceeds its contribution originating from wastewater discharges from Temelín Nuclear Power Plant. Annual discharges of strontium 90 in the period 2002-2007 were in the range $<0.0002-<0.003 \mathrm{GBq} /$ year [3].

In case of strontium 90, whose outflow from the reservoir exceeds the inflow. The percentage release was calculated by using the annual mean activity of strontium $90\left(c_{90 S r}\right)$. The percentaga release of strontium 90 was detected in the range from 10 to $59 \%$ with the average value of $31.0 \%$. An increased value was derived for the period after the flood event in 2002.

The results of the deposition analysis of suspended matter substantiate the assumption that the deposition of caesium 137 is caused mainly by sedimentation of caesium 137 component that is fixed on solid particles. This assumption is in harmony with the high level of distribution coefficient Kd for caesium 137 reported for the Constance lake and the Rhine River in the range 4.6 $10^{4}-2.7 \cdot 10^{6} 1 / \mathrm{kg}$ [4]. The decrease in the deposition of caesium 137 in Orlík reservoir with the observed (effective) half life of 8.0 years corresponds with the half life of the decrease in annual mean specific activity of caesium 137 in bottom sediments sampled from the reservoir and its tributaries with the value of 6.6 years evaluated from the results of monitoring during the period 1990-2002 [2].

The release of strontium 90 from the reservoir corresponds with its higher mobility and lower values of $\mathrm{Kd}(750-1800 \mathrm{l} / \mathrm{kg}$ ) published for the area surrounding Chernobyl Nuclear Power 
Plant [4]. The increased activity of strontium 90 at sampling sites that was detected from the monitoring after the extreme flood event in 2002 corresponds with results obtained for the Dnìpr reservoirs where significantly increased activity of strontium 90 was detected in water after the winter flood consequently to blockage of the river by ice floes [5].

The knowledge of the caesium 137 deposition and the strontium 90 release was compared with published results focused on the ratio of the mean activities of dissolved radioactive substances and suspended matter between the inflows and outflows from open European lakes and reservoirs in the period 1987-1994 that is after the Chernobyl accident [4, 6]. In case of caesium 137 the detected ratio in the individual lakes ranged from 0.08-2.22, in case of strontium 90 the detected range was 0.66-1.44. For strontium 90, the values of the ratio of its mean annual activity in the inflow and outflow from Orlík reservoir was 0.63-0.91 with the average value of 0.77 in the period 1997-2006, which was in accordance with the published results. The observed ratio of the annual mean activities of caesium 137 in the inflow and outflow from Orlík reservoir ranged from 1.56 to 4.11 with the average value of 2.73 in the period 1990-2006 and therefore this result exceeds significantly the published values $[4,6]$. The increased deposition of caesium 137 corresponds with the increased deposition of suspended matter in the range from 3.49 to 21.50 with the mean value of 9.00 derived for the identical period.

\section{CONCLUSION}

This paper provides results of monitoring of the deposition of suspended matter, caesium 137 and strontium 90 in Orlík reservoir located on the Vltava River, which receives waste waters from Temelín Nuclear Power Plant. The annual deposition of suspended matter ranged between $71-95 \%$ with the average value of $85.8 \%$. In mass unit, the annual mean deposition is 29917 tons. The annual deposition of caesium 137 is between 36 and $76 \%$ with the average value of $60.6 \%$. The annual deposition of caesium 137 activity is $1.8-19.2 \mathrm{GBq}$ and it decreased with the effective half life of 8.0 years in the period 1990-2006. The annual release of strontium 90 was detected in the range 10-59\% with the average value $31.0 \%$ and the annual released activity is $1.1-8.7 \mathrm{GBq}$. Annual activities of strontium 90 and caesium 137 discharged from Temelín Nuclear Power Plant were significantly lower than the activities in the inflow and outflow from Orlík reservoir. The concentrations of strontium 90 and caesium 137 originate from the atmospheric fall-out consequently to the tests of nuclear weapons and Chernobyl accident in the last century.

\section{Acknowledgments}

The paper was prepared from results of a MZP 0002071101 project sponsored by Ministry of the Environment of the Czech Republic.

\section{References}

[1] Hanslík, E., Sedlářová, B. and Šimonek, P., Radioprotection 37 (2002) 689-695.

[2] Hanslík, E., Jedináková-Ǩř́žová, V., Ivanovová, D., Kalinová, E., Sedlářová, B. and Šimonek, P., J. Environ. Radioaktivity 81 (2005) 307-320.

[3] Fechtnerová, M., in Annual Report (ČEZ Company, NPP Temelín, 2002, 2003, 2004, 2005, 2006, 2007).

[4] Smith, J.T. and Beresford, N.A., Chernobyl catastrophe and consequences (Praxis Publishing Ltd, Chichester, UK, 2005) pp. 154-168.

[5] Vakulovky, S.M., Nikitin, A.I., Chumichev, V.B., Katrich, I.Yu., Voitsekhovith, O.A., Medinets, V.I., Pisarev, V.V., Bovkum, L.A. and Khersonsky, E.S., J. Environ. Radioaktivity 23 (1994) 103-122

[6] Smith, J.T., Leonard, D.R.P.,. Histon, J. and Applty, P.G., Health Physics 72 (1997) 880-892. 